\title{
UJI KINERJA DAN KELAYAKAN FINANSIAL PENGERING PATI SAGU TIPE PNEUMATIC CONVEYING RING DRYER
}

\section{THE PERFORMANCE AND FINANCIAL FEASIBILITY TEST OF SAGO STARCH DRYER PNEUMATIC CONVEYING RING DRYER TYPE}

\author{
Abadi Jading ${ }^{1 凶}$, Paulus Payung ${ }^{1}$, Eduard Fransisco Tethool ${ }^{2}$ \\ ${ }^{1}$ Jurusan Teknik Pertanian dan Biosistem, Fakultas Teknologi Pertanian, Universitas Papua \\ ${ }^{2}$ Jurusan Teknologi Hasil Pertanian, Fakultas Teknologi Pertanian, Universitas Papua \\ ${ }^{\square}$ Komunikasi Penulis, email: a.jading@unipa.ac.id \\ DOI:http://dx.doi.org/10.23960/jtep-l.v10i2.228-238 \\ Naskah ini diterima pada 5 Januari 2021; revisi pada 3 April 2021; \\ disetujui untuk dipublikasikan pada 6 April 2021
}

\begin{abstract}
Sago starch drying in remote areas or difficult to reach transportation requires artificial dryers to increase the quantity and quality of the dry sago starch. The purpose of this study was to test performance, and analyze the economic value of biomass powered pneumatic conveying ring dryer (PCRD) for drying sago starch for small scale commercial. This research was conducted in two stages, namely performance testing and financial analysis. Small scale (mini) PCRD has been created for drying sago starch with a capacity of $160 \mathrm{~kg}$ of dry sago starch per day. The resulting moisture content varies according to variations in temperature and initial moisture content of sago starch and has met the Indonesia National Standard (SNI) No. 3729 regarding the maximum water content of sago starch (13\%), except at temperature variations of $50^{\circ} \mathrm{C}$ and $75^{\circ} \mathrm{C}$ with an initial moisture content of $41 \%$ that did not meet the SNI, which was greater than 13\% (14.27\% and 13.23\%). The drying efficiency varies between $7.339 \%$ to $9.689 \%$. Likewise, the yield of dry sago starch that was produced varied between $65 \%$ and 73\%. PCRD is very feasible to be developed into a commercial scale sago starch dryer with a Pay back value of 2.66 years to return the initial capital of Rp. 186,879,200.
\end{abstract}

Keywords: drying, financial analysis, PCRD, sago starch

\begin{abstract}
ABSTRAK
Pengeringan pati sagu pada daerah terpencil atau sulit terjangkau transportasi memerlukan pengering buatan untuk meningkatkan kuantitas dan kualitas pati sagu kering tersebut. Tujuan penelitian ini adalah menguji kinerja, dan menganalisis nilai ekonomis pneumatic conveying ring dryer (PCRD) bertenaga biomassa untuk pengeringan pati sagu skala usaha rakyat Penelitian ini dilakukan dalam dua tahapan yaitu pengujian kinerja dan analisis finansial. PCRD skala kecil (mini) telah diciptakan untuk pengeringan pati sagu kapasitas $160 \mathrm{~kg}$ pati sagu kering per hari. Kadar air yang dihasilkan bervariasi sesuai dengan variasi suhu dan kadar air awal pati sagu dan telah memenuhi standar Nasional Indonesia (SNI) No. 3729 tentang kadar air maksimum pati sagu (13\%), kecuali pada variasi suhu $50^{\circ} \mathrm{C}$ dan $75^{\circ} \mathrm{C}$ dengan kadar air awal $41 \%$ belum memenuhi SNI, yaitu lebih besar dari 13\% (14,27\% dan 13,23\%). Efisiensi pengeringan bervariasi antara antara 7,339\% sampai 9,689\%. Begitupula dengan rendemen pati sagu kering yang dihasilkan bervariasi antara 65\% sampai 73\%. PCRD sangat layak dikembangkan menjadi pengering pati sagu skala komersial dengan nilai Pay back periode 2,66 tahun untuk mengembalikan modal awal sebesar Rp. 186.869.200.
\end{abstract}

Kata Kunci: pengeringan, analisis finansial, PCRD, pati sagu

\section{PENDAHULUAN}

Proses pengeringan merupakan salah satu solusi untuk mengurangi bobot bahan, termasuk pati sagu basah sehingga pengangkutannya lebih mudah, masa simpannya lebih lama, dan nilai tambahnya lebih meningkat. Pengolahan pati sagu skala rakyat umumnya dilakukan pada daerah yang sulit terjangkau sarana transportasi, sehingga pengeringan sangat diperlukan untuk 
mengurangi bobot pati sagu basah. Pengeringan pati sagu pada daerah yang sulit terjangkau transportasi atau terpencil dilakukan dengan cara penjemuran menggunakan sinar matahari tanpa menggunakan alat buatan, sehingga kuantitas dan kualitasnya cukup rendah. Hal ini disebabkan belum tersedianya pengering buatan yang sesuai dan layak secara teknis dan ekonomis (finansial) untuk digunakan pada daerah tersebut, terutama dalam skala kelompok usaha rakyat.

Pneumatic conveying ring dryer (PCRD) adalah salah satu pengering buatan yang paling sesuai digunakan untuk pengeringan pati sagu skala rakyat di daerah terpencil. PCRD adalah pengembangan dari Pneumatic conveying dryer atau flash dryer yang memiliki konstruksi yang sederhana, mudah dioperasikan, biaya operasionalnya murah, dan efisiensinya cukup tinggi (Jading, 2018). Pneumatic conveying ring dryer telah dikembangkan untuk pengeringan pati sagu. Namun demikian, PCRD tersebut memiliki beberapa kekurangan diantaranya, kapasitas input bahan rendah, dan sumber pemanasannya menggunakan bahan bakar gas (BBG) Liquid Petroleum Gas (LPG) (Jading et al., 2016; Jading, 2018).

Untuk memperbaiki kekurangan pada PCRD tersebut, telah dilakukan pengembangan kapasitas input bahan bertenaga biomassa dengan merancang bangun sistem pengumpan tipe screw conveyor (SC) dan tungku biomassa (Jading et al., 2019). Namun demikian kinerja dari PCRD belum diketahui. Oleh karena itu perlu dilakukuan pengujian kinerja dengan melakukan variasi beberapa variabel perlakuan untuk mengamati parameter kinerja dari PCRD tersebut. Selain itu, untuk menguji kelayakan PCRD hasil rancang bangun tersebut, maka dilakukan analisis finansial. Pengujian kelayakan beberapa pengering buatan telah dilakukan antara lain oleh Purbono et al. (2010), Paisal et al. (2018), serta Prasnowo dan Nurdin, (2019).

Beberapa penelitian terdahulu lainnya sebagai pendukung penelitian ini, antara lain pengujian kinerja flash dryer yang telah dilakukan oleh Ajao dan Adegun (2019) flash dryer untuk pengeringan tapioka, Kuye et al. (2011) flash dryer untuk pengeringan tapioka kapasitas 1 ton/jam, Kusharjanto et al. (2013) flash dryer untuk pengeringan mocaf, Suherman et al. (2015) flash dryer untuk pengeringan tapioka, Witdarko et al. (2016) flash dryer untuk pengeringan tapioka, dan Chapius et al. (2017) flash dryer untuk pengeringan tapioka.

Penelitian-penelitian tersebut belum menggunakan proses resirkulasi bahan secara kontinyu atau ring dryer. Selain itu, penelitian tersebut umumnya bertenaga BBG dan Listrik, kecuali pengembangan PCD bertenaga biomassa untuk pengeringan tapioka oleh Kuye et al. (2011). Oleh karena itu, penelitian ini merupakan hal yang baru untuk mendukung penguatan agroindustri sumber daya lokal berbasis sagu pada daerah terpencil. Tujuan penelitian ini adalah menguji kinerja dan menganalisis nilai ekonomis pneumatic conveying ring dryer (PCRD) bertenaga biomassa untuk pengeringan pati sagu skala usaha rakyat.

\section{BAHAN DAN METODE}

Bahan dan alat yang digunakan pada penelitian ini terdiri dari 2 bagian. Pertama, bahan untuk pembuatan PCRD (besi siku, plat stainless steel, dan bahan pendukung lainnya). Kedua, bahan pengujian PCRD (pati sagu basah dan bahan bakar biomassa berupa tongkol jagung, yang diperoleh dari masyarakat di daerah Manokwari, Papua Barat). Alat yang digunakan untuk pembuatan PCRD adalah mesin perbengkelan utama (mesin las, bubut, dan instrumen pengukur lainnya). Sedangkan peralatan yang digunakan untuk pengujian kinerja PCRD terdiri dari alatalat ukur seperti flexible thermo-anemometer merek KRISBOW KW06-562, thermometer digital merek Lutron BTM-4208SD dengan termokopel tipe $\mathrm{K}$, tachometer digital merek Lutron DT-1236L, thermometer analog merek WIPRO, hygrometer digital merek KRISBOW KW06-291, moisture analyzer balance merek RADWAG MA 50 R, timbangan duduk analog, timbangan analitik merek HWH max $60 \mathrm{~g}$, stopwatch, dan peralatan-peralatan pendukung lainnya.

Pembuatan PCRD dilakukan di unit perbengkelan agroindustri, Laboratorium 
Teknik Pertanian Jurusan Teknik Pertanian dan Biosistem Fakultas Teknologi Pertanian, Universitas Papua. Sedangkan pengujian kinerja PCRD dilakukan di usaha pengolahan sagu dan umbi-umbian SAGUMBI yang terletak di Kampung Bowi Subur, Distrik Masni, Manokwari Papua Barat.

Penelitian ini dilakukan dalam dua tahapan. Tahapan pertama adalah pengujian kinerja PCRD dan tahapan kedua adalah analisis nilai nilai ekonomis untuk mengetahui tingkat kelayakan PCRD apabila digunakan pada pengeringan pati sagu. Sebelum melakukan pengujian kinerja PCRD tersebut, terlebih dahulu dilakukan pembuatan bagian-bagian utama PCRD sesuai skema rancangan seperti pada Gambar 1. Komponen utama PCRD terdiri dari tungku biomassa, pipa resirkulasi, blower disintegrator, blower resirkulasi bahan, siklon resirkulasi bahan, siklon output bahan, dan penampung bahan.
Untuk menentukan ukuran bagian-bagian PCRD (pipa resirkulasi, siklon resirkulasi, siklon output, dan blower), maka digunakan analisis matematis (Jading, 2018). Diameter pipa resirkulasi ditentukan dengan Persamaan 1 sampai 6 (Kuye et al., 2011; Jading, 2018; Singh dan Heldman, 2009; Brooker et al., 1992).

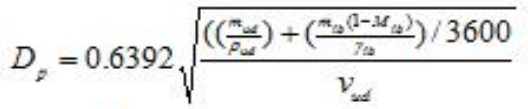

$$
\begin{aligned}
& m_{\mathrm{ud}}=\frac{Q_{t}}{\Delta h} \\
& Q_{t}=\left[\left[\left(m_{i b}\left(1-M_{i b}\right)\right)-\left(\frac{m_{i b}\left(1-M_{i b}\right)}{1-M_{a b}}\right)\right] H f g\right]+ \\
& {\left[\left(m_{i b}\left(1-M_{i b}\right)\right) C_{p i b}\left(T_{\alpha p}-T_{\text {lisg }}\right)\right]} \\
& H f g=2,503 \times 10^{6}-2,386 \times 10^{3}\left(T_{o p}-273,16\right)
\end{aligned}
$$

Dimana, $273,16 \leq \mathrm{T}_{\text {op }}(\mathrm{K}) \leq 338,72$.

$$
H f g=\left(7,33 \times 10^{12}-1,60 \times 10^{7} T_{o p}{ }^{2}\right)^{0.5}
$$

Dimana, $338,72<T_{\text {op }}(K) \leq 533,16$.

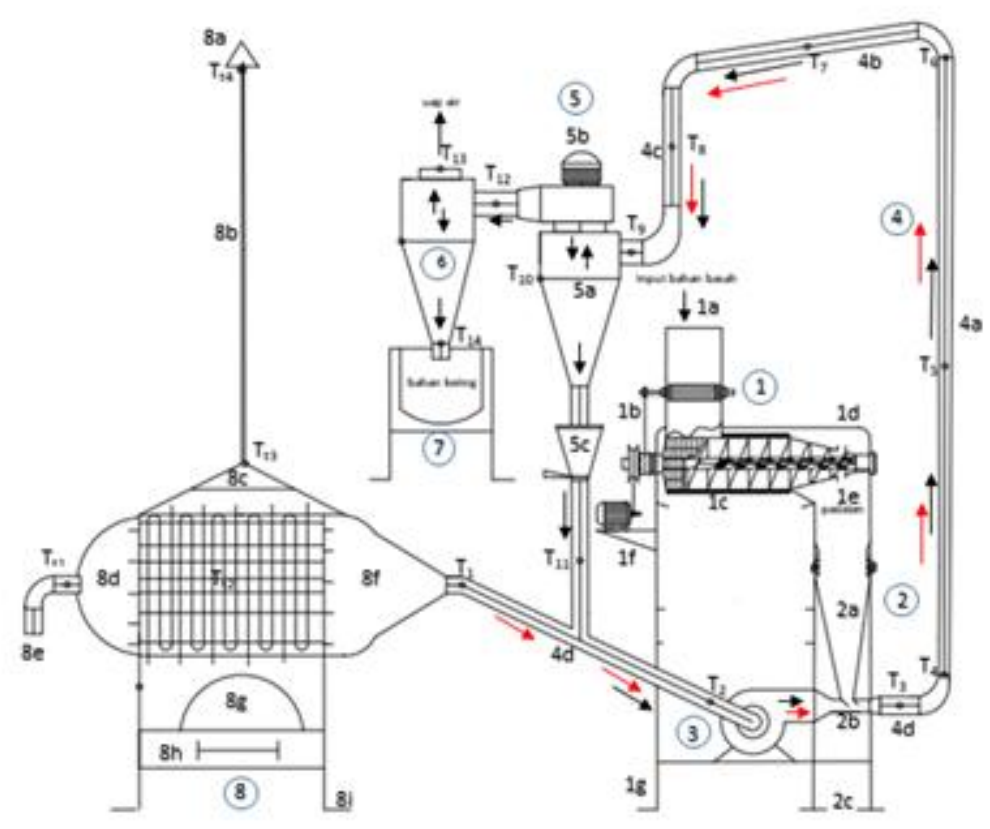

\section{Keterangan:}

1) Sistem pengumpan: $1 \mathrm{a}$. hoper, $1 \mathrm{~b}$. siilinder bergigi, $1 \mathrm{c}$. screw conveyor, $1 \mathrm{~d}$. chasing, 1e. outlet padatan 1f. motor penggerak, $1 \mathrm{~g}$. rangka, 2) sambungan pengumpan ke pipa resirkulasi: $2 \mathrm{a}$. pipa vertikal, $2 \mathrm{~b}$. pipa ventury, 2c. rangka, 3) blower disintegrtor, 4) pipa resirkulasi: $4 \mathrm{a}$. vertikal upriser, $4 \mathrm{~b}$. $u$-bend, 4c. vertikal downcomer, 4d. horisontal, 5) manifold: $5 \mathrm{a}$. siklon resirkulasi, 5b. blower, 5c. pengatur resirkulasi, 6) siklon output bahan, 7) penampung bahan kering, 8) tungku biomassa: 8a. tutup cerobong, $8 \mathrm{~b}$. pipa cerobong asap, $8 \mathrm{c}$. penutup tungku, $8 \mathrm{~d}$. penutup heatexcahnger, $8 \mathrm{e}$. pipa udara masuk, 8 . ruang udara panas, $8 \mathrm{~g}$. ruang pembakaran, $8 \mathrm{~h}$. ruang abu, $8 \mathrm{i}$. rangka, dan $\mathrm{T}=$ titik pengukuran suhu, tanda panah merah adalah udara pengering, tanda panah hitam adalah bahan

\section{Gambar 1. Skema Rancangan PCRD Bertenaga Biomassa}




$$
\begin{aligned}
C_{p i b}= & 1,424 m_{c s s}+1,549 m_{p r o}+1,675 m_{j \in t}+ \\
& 0,837 m_{a s h}+4,187 M_{i b}
\end{aligned}
$$

Dimana, $\mathrm{D}_{\mathrm{p}}$ diameter pipa bagian dalam (m), $\gamma_{\mathrm{ib}}$ bulk densitas bahan setelah pengumpanan $(\mathrm{kg} /$ $\left.\mathrm{m}^{3}\right), \mathrm{m}_{\mathrm{ud}}$ massa udara pengering $(\mathrm{kg}), \Delta \mathrm{h}$ perubahan entalpi udara setelah dipanaskan (J/ $\mathrm{kg}$ ), $Q_{\mathrm{t}}$ total panas (J), $\mathrm{m}_{\mathrm{ib}}$ massa input bahan basah (kg), $M_{\mathrm{ib}}$ kadar air awal bahan (desimal), $\mathrm{M}_{\mathrm{ob}}$ kadar air akhir bahan (desimal), Hfg panas laten penguapan $(\mathrm{J} / \mathrm{kg}), \mathrm{T}_{\text {op }}$ suhu input bahan basah $\left({ }^{\circ} \mathrm{C}\right), \mathrm{C}_{\text {pib }}$ panas jenis bahan input $\left(\mathrm{J} / \mathrm{kg}^{\circ} \mathrm{C}\right)$, dan $\mathrm{T}_{\text {ling }}$ suhu lingkungan $\left({ }^{\circ} \mathrm{C}\right), \mathrm{m}_{\mathrm{car}}$ kadar karbohidrat (\%), $\mathrm{m}_{\text {pro }}$ kadar protein (\%), $\mathrm{m}_{\text {fat }}$ kadar lemak (\%), dan $\mathrm{m}_{\text {ash }}$ kadar abu input bahan (\%).

Panjang pipa resirkulasi ditentukan dengan Persamaan 7 sampai 10 (Kuye et al., 2011;Tanaka et al., 2008).

$$
\begin{aligned}
& L_{p}=v_{\text {act }} \cdot t_{r} \\
& v_{a c t}=v_{t e r-\min } \cdot f_{k} \\
& v_{t e r-\min }=\sqrt{\frac{4 D_{i b}\left(\rho_{\text {ub }}-\rho_{u d}\right) g}{3 \rho_{u d} C_{D}}} \\
& C_{D}= \begin{cases}\frac{24}{R_{c}}\left(1+0,15 R_{c}^{0,637}\right) & R_{\varepsilon} \leq 1000 \\
0,44 & R_{\varepsilon}>1000\end{cases}
\end{aligned}
$$

Dimana, $\mathrm{L}_{\mathrm{p}}$ panjang pipa resirkulasi bahan $(\mathrm{m})$, $\mathrm{v}_{\text {act }}$ kecepatan sebenarnya $(\mathrm{m} / \mathrm{s}), \mathrm{t}_{\mathrm{r}}$ waktu tinggal (residence time) bahan di dalam pipa atau kolom pengering $(\mathrm{s}), \mathrm{f}_{\mathrm{k}}$ faktor keamanan $(1,1), \mathrm{v}_{\text {ter }^{\prime}}, \mathrm{D}_{\mathrm{ib}}$ $\rho_{\text {ud }}$ g, dan $C_{D}$ adalah kecepatan terminal $(\mathrm{m} / \mathrm{s})$, diameter input bahan $(\mathrm{m})$, densitas udara pengering $\left(\mathrm{kg} / \mathrm{m}^{3}\right)$, percepatan gravitasi $\left(\mathrm{m} / \mathrm{s}^{2}\right)$, dan nilai koefisien gesek. dimana $\mathrm{R}_{\mathrm{e}}$ bilangan Reynolds (Reynolds Number).

Kecepatan udara di dalam siklon dihitung dengan Persamaan 11 dan 12 (Jading, 2018).

$$
\begin{aligned}
& v_{u}=\frac{Q_{u}}{W\left(D_{s}-D_{A}\right)} \\
& D_{s}=\left(\frac{5,7 x Q_{u}}{v_{u}}\right)^{0,5}
\end{aligned}
$$

Dimana, W lebar inlet siklon $(\mathrm{m}), \mathrm{D}_{\mathrm{s}}$ diameter silinder siklon $(\mathrm{m}), \mathrm{D}_{\mathrm{A}}$ diameter outlet udara atau cerobong siklon (m). Ukuran bagian-bagain pada siklon resirkulasi dan output bahan ditentukan dengan perbandingan antara diameter siklon $\left(D_{s}\right)$ terhadap bagian-bagian siklon tersebut. Ukuran panjang pipa outlet atas siklon $\left(\mathrm{L}_{\mathrm{A}}\right)$ adalah $L_{A} / D_{s} 0,5-0,625$. Ukuran tinggi silinder siklon $\left(\mathrm{L}_{\mathrm{s}}\right)$ adalah $\mathrm{L}_{\mathrm{s}} / \mathrm{D}_{\mathrm{s}} 2-2,5$. Ukuran tinggi kerucut siklon $\left(\mathrm{L}_{c}\right)$ adalah $\mathrm{L}_{c} / \mathrm{D}_{\mathrm{s}} 1,5-2$. Ukuran diameter outlet bawah $\left(\mathrm{D}_{\mathrm{B}}\right)$ adalah $\mathrm{D}_{\mathrm{B}} / \mathrm{D}_{\mathrm{s}} 0,25$ 0,375 . Ukuran diameter outlet udara atau cerobong siklon $\left(D_{A}\right)$ adalah $D_{A} / D_{S} 0,5$. Ukuran panjang sisi inlet $(\mathrm{H})$ adalah $\mathrm{H} / \mathrm{D}_{\mathrm{s}} 0,5-0,6$. Ukuran lebar sisi inlet (W) adalah $\mathrm{W} / \mathrm{D}_{\mathrm{s}}$ 0,2-0,25 (Lydersen, 1978; Jading, 2018).

Perhitungan nilai panas yang dihasilkan tungku biomassa didasarkan pada analisis energi panas pipa pemindah panas (heat exchanger) menggunakan Persamaan 13 sampai 15.

$$
\begin{aligned}
& E_{p a}=\left(\frac{M_{i b}-M_{o b}}{1-M_{o b}}\right) m_{i b} H f g \\
& N_{b b m}=\frac{E_{p a}}{q_{p b}} \\
& A_{h e}=\frac{E_{p a}}{h_{p i p a} \Delta T} \\
& N_{p p}=\frac{A_{h e}}{\pi L_{p p} D_{d p}}
\end{aligned}
$$

Dimana, $\mathrm{E}_{\mathrm{pa}}$ adalah jumlah energi panas minimal pipa pemindah panas (heat exchanger, $\mathrm{M}_{\mathrm{ib}}$ adalah kadar air awal, $\mathrm{M}_{\mathrm{ob}}$ adalah kadar air akhir bahan, $\mathrm{m}_{\mathrm{ib}}$ adalah massa bahan, $\mathrm{Hfg}$ adalah panas penguapan bahan, $\mathrm{N}_{\mathrm{bbm}}$ adalah jumlah bahan bakar biomassa dalam tungku, $\mathrm{q}_{\mathrm{pb}}$ adalah nilai panas pembakaran Biomassa, $\mathrm{A}_{\mathrm{he}}$ adalah luas penampang heat exchanger, $\mathrm{h}_{\mathrm{pipa}}$ adalah nilai koefisien panas pipa, $\Delta \mathrm{T}$ adalah perubahan suhu, Npp adalah Jumlah potongan pipa secara teoritis, $\mathrm{L}_{\mathrm{pp}}$ adalah panjang potongan pipa, dan $\mathrm{D}_{\mathrm{dp}}$ adalah diameter dalam pipa.

Pengujian kinerja PCRD dilakukan untuk mengetahui kadar air akhir bahan $\left(\mathrm{M}_{\mathrm{ob}}\right)$, efisiensi pengeringan $\left(\eta_{\mathrm{pe}}\right)$, dan rendemen pati kering $\left(\eta_{\mathrm{b}}\right)$. Adapun prosedur pengujian kinerja PCRD tersebut adalah sebagai berikut, sampel pati sagu basah sebanyak $200 \mathrm{~kg}$ dikempa menggunakan pengempa hidrolik manual kapasitas 10 ton. Lama pengempaan pada setiap sampel disesuaikan dengan variasi kadar air awal bahan $(21 \%, 31 \%, 41 \%)$ sebagai variabel perlakuan. 
Nilai kadar air awal pati sagu yang telah dikempa, diukur secara langsung menggunakan moisture analyzer balance. Sampel pati sagu basah yang telah dikempa tersebut kemudan ditimbang sebanyak $5 \mathrm{~kg}$, sebagai sampel pengujian kinerja PCRD. Setiap sampel pati sagu $(5 \mathrm{~kg})$ dimasukkan melalui hoper pada screw conveyor, kemudian dialirkan menuju pipa pengering. Suhu di dalam pipa pengering divariasi $\left(50^{\circ} \mathrm{C}\right.$, $75^{\circ} \mathrm{C}$, dan $100^{\circ} \mathrm{C}$ ), sebagai variabel perlakuan.

Oleh karena itu, variabel perlakuan meliputi kadar air awal pati sagu $\left(\mathrm{M}_{\mathrm{ib}}\right)$, dan suhu udara pengering $\left(\mathrm{T}_{\mathrm{u}}\right)$. Sedangkan parameter pengamatan meliputi kadar air akhir pati sagu kering $\left(M_{o b}\right)$, efisiensi pengeringan $\left(\eta_{p e}\right)$, dan rendemen pati kering $\left(\eta_{b}\right)$. Kombinasi dari variabel perlakuan tersebut dengan jumlah pengulangan sebanyak 3 kali, menghasilkan data sebanyak 27 buah.

Kadar air akhir pati sagu $\left(\mathrm{M}_{\mathrm{ob}}\right)$ ditentukan melalui pengukuran secara langsung menggunakan moisture analyzer balance, seperti pada penentuan kadar air awal pati sagu. Sedangkan efisiensi pengeringan $\left(\eta_{\mathrm{pe}}\right)$ dan rendemen bahan kering $\left(\eta_{b}\right)$ diperoleh melalui analisis matematis menggunakan Persamaan 17 sampai 20 (Jading, 2018).

$$
\begin{aligned}
& \eta_{p e}=\frac{q_{t}}{\Delta h \cdot \dot{m}_{u}} \times 100 \% \\
& q_{t}=\frac{Q_{t}}{t} \\
& \dot{m}_{u}=\rho_{u} \cdot A_{o b l} v_{u} \\
& \eta_{b}=\frac{m_{o b}}{m_{i b}} x 100 \%
\end{aligned}
$$

Dimana, $\mathrm{q}_{\mathrm{t}}$ adalah laju aliran panas yang dibutuhkan untuk menguapkan air dalam bahan (panas laten) dan menaikkan suhu bahan (panas sensibel) $(\mathrm{kJ} / \mathrm{s}), \Delta \mathrm{h}$ adalah perubahan entalpi $(\mathrm{kJ} / \mathrm{kg}), \mathrm{m}_{\mathrm{u}}$ adalah kapasitas udara pengering $(\mathrm{kg} / \mathrm{s}) \cdot \mathrm{Q}_{\mathrm{t}}$ adalah jumlah panas laten dan sensibel $(\mathrm{kJ}), \mathrm{t}$ adalah waktu pengeringan (s), $\rho_{\mathrm{u}}$ adalah densitas udara pengering $\left(\mathrm{kg} / \mathrm{m}^{3}\right), \mathrm{A}_{\mathrm{obl}}$ adalah luas penampang outlet blower $\left(\mathrm{m}^{2}\right), \mathrm{v}_{\mathrm{u}}$ adalah kecepatan aliran udara pengering $(\mathrm{m} / \mathrm{s}), \eta_{b}$ adalah rendemen bahan $(\%), \mathrm{m}_{\mathrm{ib}}, \mathrm{m}_{\mathrm{ob}}$ adalah massa input bahan (kg) dan massa output bahan (kg).

Analisis ekonomis bertujuan untuk memperkirakan dan memperhitungkan keuntungan yang diperoleh dalam pengembangan PCRD apabila digunakan pada pengeringan pati sagu. Kriteria-kriteria yang digunakan dalam analisis ekonomis tersebut adalah Net Present Value (NVP), Internal Rate off Return (IRR), laba setelah pajak (EAT), Average Rate of Return (ARR), Net Benefit-Cost Ratio (Net B/C), Break Event Point (BEP) dan Pay Back Period (PBP) (Husnan dan Suwarsono, 1997; Jading et al., 2014a; Jading et al., 2014). Adapun asumsi-asumsi yang digunakan untuk melakukan analisis ekonomis PCRD tersebut yaitu bunga modal $17 \%$, nilai penyusutan $\mathrm{Rp}$. 28.672.000, dan tenaga kerja yang diperlukan sebanyak 2 orang yaitu 1 orang operator/teknisi PCRD, dan 1 orang untuk mengontrol proses pengeringan. Data yang dihasilkan pada penelitian ini, diolah dan disajikan dalam bentuk gambar (grafik) serta tabel, kemudian dianalisis secara deskriptif.

\section{HASIL DAN PEMBAHASAN}

Konstruksi Pneumatic Conveying Ring Dryer (PCRD), dapat dilihat pada Gambar 2. Kapasitas produksi PCRD adalah $160 \mathrm{~kg}$ pati sagu kering per hari. Bagian-bagain dari PCRD terdiri dari beberapa bagian utama yaitu, sistem pengumpan (Jading et al., 2019), sumber pemanas (tungku biomassa), blower disintegrator, pipa resirkulasi bahan, siklon resirkulasi bahan, siklon output bahan, dan bak penampung. Adapun bagian utama tersebut akan dijelaskan berikut ini.

Konstruksi tungku biomassa tipe down draft berbahan bakar tongkol jagung dapat dilihat pada Gambar 3. Tungku biomassa terdiri dari ruang pembakaran berukuran $(70 \times 70 \times 70) \mathrm{cm}$, dan ruang pemindah panas (heat exchanger) berukuran $(60 \times 60 \times 150) \mathrm{cm}$. Tungku biomassa terbuat dari pelat besi $2 \mathrm{~mm}$. Di dalam ruang pemindah panas dilengkapi pipa-pipa besi galvanis berdiameter $5 \mathrm{~cm}$, serta berukuran panjang $170 \mathrm{~cm}$, sebanyak 13 batang dengan jarak tertentu. Panas yang dihasilkan pada ruang pemidah panas adalah $400^{\circ} \mathrm{C}$, sehingga distribusi 

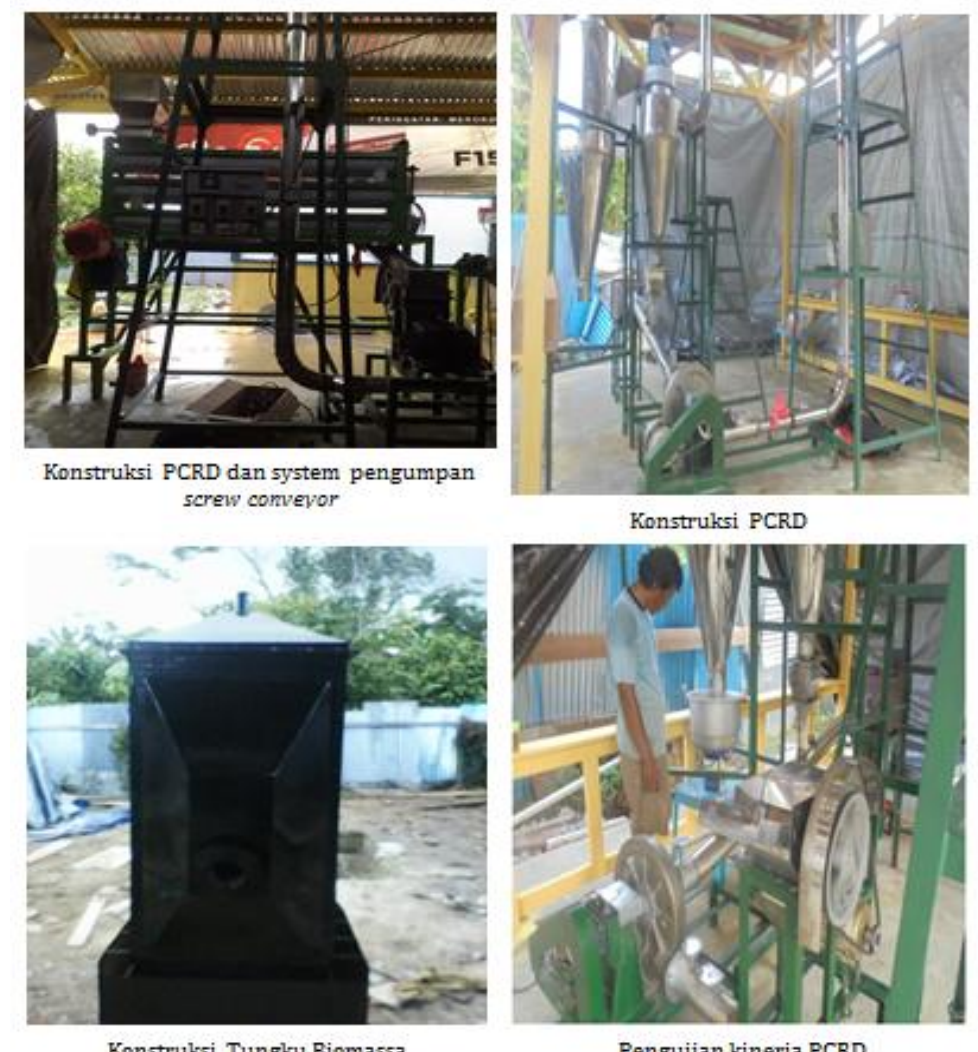

Pengujian kinerja PCRD

Gambar 2. Konstruksi dan Pengujian PCRD, Screw Conveyor, dan Tungku Biomassa

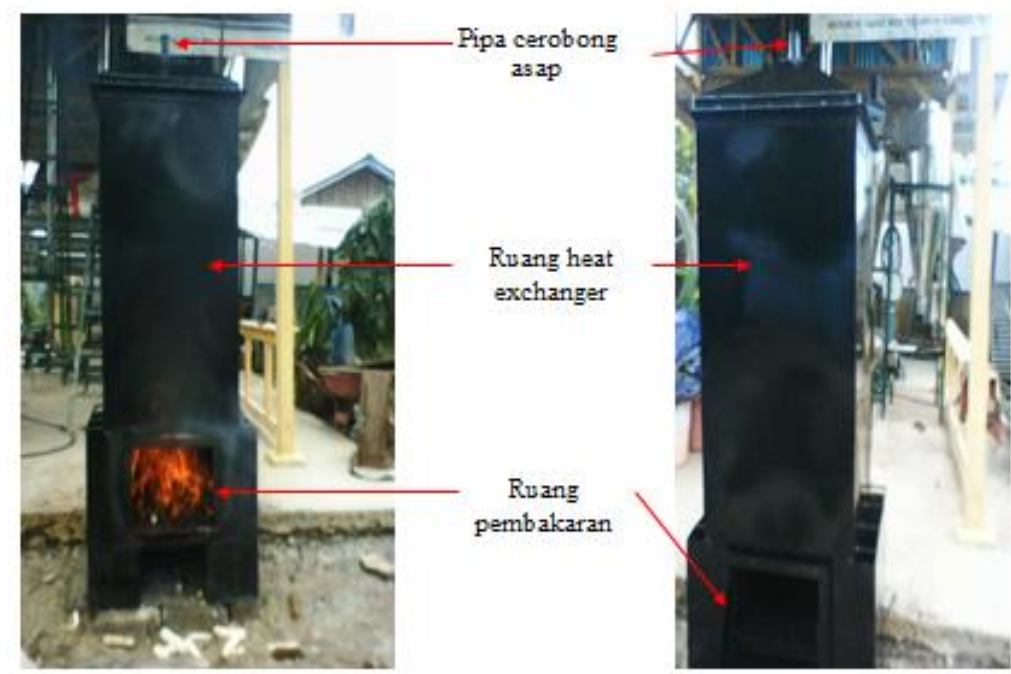

Gambar 3. Pengujian Kinerja Tungku Biomassa dengan Ruang Heat Exchanger

suhu ke dalam pipa resirkulasi PCRD mampu mencapai $150^{\circ} \mathrm{C}$.

Blower disintegrator berfungsi sebagai penghisap dan penghembus udara panas dari tungku biomassa. Selain itu, blower disintegrator juga berfungsi sebagai penghembus bahan input atau pati sagu basah yang keluar masuk ke dalam pipa resirkulasi dari sistem pengumpan. Bahan tersebut dialirkan menuju siklon resirkulasi dan siklon output bahan. Kecepatan aliran udara blower yang digunakan adalah $15 \mathrm{~m} / \mathrm{s}$. Menurut Chapius et al. (2017) kecepatan udara pengering pneumatic conveying dryer (PCD) adalah 9,8$23,8 \mathrm{~m} / \mathrm{s}$.

Pipa resirkulasi terdiri dari pipa upriser atau vertical keatas, horizontal, downcomer atau 
vertical ke bawah. Diameter dan panjang pipa resirkulasi sesuai hasil perhitungan menggunakan Persamaan 1 dan 7 masingmasing adalah 0,1016 $\mathrm{m}$ (4 inci) dan 9,38 m. Hal ini menunjukkan bahwa rancangan PCRD ini merupakan skala mini atau kecil. Chapius et al. (2017) menyebutkan bahwa PCD skala besar umumnya memiliki diameter pipa 1-1,5 m, dengan panjang pipa $20-60 \mathrm{~m}$.

Siklon resirkulasi bahan berdiameter $0,5 \mathrm{~m}$ dengan tinggi $1,2 \mathrm{~m}$. Ukuan bagian-bagian siklon resirkulasi yaitu $\mathrm{L}_{\text {scrb }} 0,27 \mathrm{~m}, \mathrm{D}_{\text {Acrb }} 0,016 \mathrm{~m}, \mathrm{~L}_{\text {Acrb }}$ 0,2 m. Pada siklon resirkulasi bahan dilengkapi blower dengan kecepatan $\mathrm{v}_{\text {ucrb }} 15,75 \mathrm{~m} / \mathrm{s}$. Blower tersebut berfungsi mengatur resirkulasi bahan basah dan bahan kering.

Bahan yang basah diresirkulasi kembali melalui pipa resirkulasi, sedangkan bahan yang kering dialirkan menuju siklon output berdiameter 0,5 $\mathrm{m}$ dengan tinggi 2,5 m. Pada siklon output bahan terjadi pemisahan antara bahan kering dengan uap air. Bahan kering ditampung pada bak penampung bahan kering.

Hasil pengukuran suhu sepanjang pipa resirkulasi sampai siklon output bahan dapat dilihat pada Gambar 4. Distribusi suhu di dalam pipa resirkulasi PCRD tersebut menunjukkan bahwa suhu tetap stabil. Titik pengukuran suhu dapat dilihat pada Gambar 1. Suhu pada titik 1 $\left(\mathrm{T}_{1}\right)$ adalah suhu output tungku biomassa pada ruang pemindah panas. $\mathrm{T}_{2}$ adalah suhu input blower disintegrator, $\mathrm{T}_{3}$ adalah suhu output blower disintegrator, $\mathrm{T}_{4}-\mathrm{T}_{6}$ adalah suhu di dalam pipa upriser (pipa vertikal keatas, atau ruang pengeringan bahan), $\mathrm{T}_{7}$ adalah suhu di dalam pipa horizontal atas, $\mathrm{T}_{8}-\mathrm{T}_{9}$ adalah suhu di dalam pipa downcomer (pipa vertikal ke bawah), $\mathrm{T}_{10}$ adalah suhu output siklon resirkulasi bahan, dan $\mathrm{T}_{11}$ adalah suhu output pada siklon output bahan (suhu output pengering).

Berdasarkan grafik pada Gambar 4 tersebut, maka suhu udara input yang digunakan untuk masing-masing perlakuan suhu berbeda-beda. Suhu perlakuan dilakukan pada titik pengukuran $\left(\mathrm{T}_{4}\right)$. Untuk perlakuan suhu $50^{\circ} \mathrm{C}\left(\mathrm{T}_{4}\right)$, maka suhu udara input $\left(\mathrm{T}_{1}\right)$ adalah $140^{\circ} \mathrm{C}$. Perlakuan suhu $100^{\circ} \mathrm{C}\left(\mathrm{T}_{4}\right)$ menggunakan suhu udara input yang masuk ke dalam pipa PCRD $\left(\mathrm{T}_{1}\right)$ adalah $205^{\circ} \mathrm{C}$. Perlakuan suhu $125^{\circ} \mathrm{C}\left(\mathrm{T}_{4}\right)$, maka suhu udara input $\left(\mathrm{T}_{1}\right)$ yang terukur adalah $275^{\circ} \mathrm{C}$

\subsection{Kadar Air Akhir Pati Sagu}

Nilai kadar akhir akhir pati sagu $\left(\mathrm{M}_{\mathrm{ob}}\right)$ yang dihasilkan PCRD dapat dilihat pada Tabel 1. Berdasarkan data pada Tabel 1 tersebut, diperoleh hasil pengukuran $M_{o b}$ dengan kombinasi perlakuan suhu udara $\left(\mathrm{T}_{\mathrm{u}}\right)$ dengan kadar air awal pati sagu $\left(\mathrm{M}_{\mathrm{ib}}\right)$. Pada kombinasi $\mathrm{T}_{\mathrm{u}}\left(50^{\circ} \mathrm{C}, 75^{\circ} \mathrm{C}, 100^{\circ} \mathrm{C}\right)$ dengan $\mathrm{M}_{\mathrm{ib}}(21 \%)$, diperloleh nilai $\mathrm{M}_{\mathrm{ob}}$ masing-masing sebesar sebesar 8,17\%, 7,20\%, dan 6,83\%. Nilai $\mathrm{M}_{\text {ob }}$ pada kombinasi $\mathrm{T}_{\mathrm{u}}\left(50^{\circ} \mathrm{C}, 75^{\circ} \mathrm{C}, 100^{\circ} \mathrm{C}\right)$ dengan $\mathrm{M}_{\mathrm{ib}}$ (31\%) adalah masing-masing $11,01 \%, 10,50 \%$, 9,00\%. Kombinasi perlakuan $\mathrm{Tu}\left(50^{\circ} \mathrm{C}, 75^{\circ} \mathrm{C}\right.$, $100^{\circ} \mathrm{C}$ ) dengan $\mathrm{M}_{\mathrm{ib}}(41 \%)$ menghasilkan nilai Mob masing-masing sebesar 14,27\%, 13,23\%,

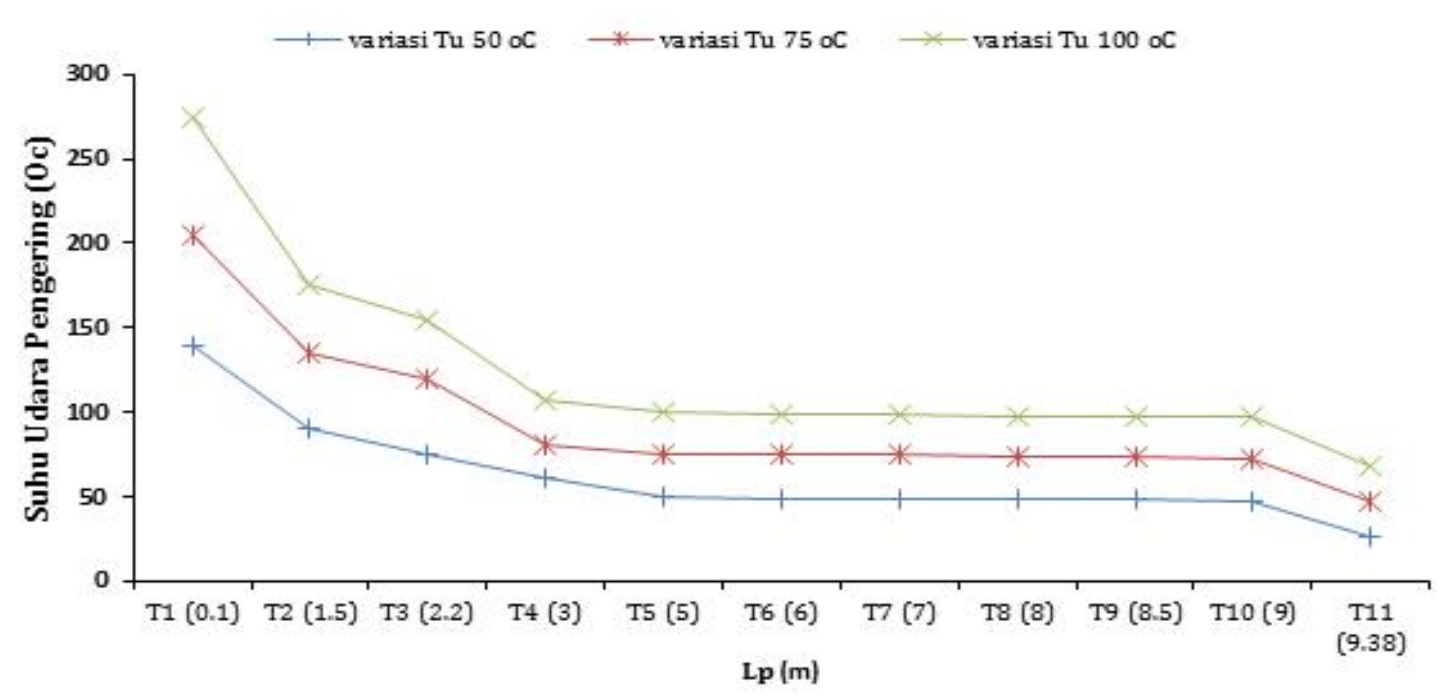

Gambar 4. Distribusi Suhu Sepanjang Pipa Resirkulasi Sampai Siklon Output Bahan 
dan 12,40\%. Berdasarkan kombinasi perlakuan tersebut, menunjukkan bahwa kadar air akhir $\left(\mathrm{M}_{\mathrm{ob}}\right)$ pati sagu bervariasi antara 6,83\% sampai $14,27 \%$. Nilai kadar air yang dihasilkan pada penelitian ini mendekati penelitian sebelumnya oleh Jading, 2018 (10-12\%), Jading et al., 2018 (9-11\%), Witdarko et al., 2016 (10,13\%), kecuali nilai kadar yang cukup tinggi pada perlakuan kombinasi $\mathrm{T}_{u}\left(50^{\circ} \mathrm{C}\right)$ dengan $\mathrm{M}_{\mathrm{ib}}(41 \%)$. Hal ini menunjukkan bahwa penggunaan suhu tersebut belum mampu menurunkan kadar air pati sagu untuk mencapai kadar air maksimal pati sagu kering sesuai Standar Nasional Indonesia (SNI) No. 3729 yaitu 13\% (Badan Standar Nasional, 2008). Begitupula dengan variasi suhu $75^{\circ} \mathrm{C}$ dengan kadar air 41\%, belum mampu menurunkan kadar air menjadi 13\%. Untuk dapat menurunkan kadar akhir pati sagu sesuai dengan SNI 3729, maka dapat dilakukan penambahan waktu pengeringan pati sagu dengan resirkulasi bahan secara kontinyu di dalam pipa pengering. Namun demikian, suhu yang terbaik digunakan untuk mengeringkan pati sagu adalah $100^{\circ} \mathrm{C}$ dengan perlakuan kadar air awal pati sagu 21-41\%, yang mampu mencapai standar SNI No. 3729.

\subsection{Efisiensi Pengeringan}

Nilai efisiensi pengering yang dihasilkan PCRD untuk mengeringkan pati sagu dapat dilihat pada Tabel 2. Data pada Tabel 2 menunjukkan bahwa nilai efisiensi PCRD bertenaga biomassa hampir sama dengan nilai efisiensi PCRD bertenaga bahan bakar LPG, yaitu 8,43\% (Jading, 2018). Begitu pula dengan nilai efisiensi pengeringan
PCD non resirkulasi yang memiliki kapasitas yang sama yaitu 13,73\% (Nugroho et al., 2012a; Nugroho et al., 2012b). Hal ini menunjukkan bahwa tungku biomassa mampu menghasilkan dan menyuplai udara panas ke dalam pipa pengering dengan baik.

\subsection{Rendemen Pati Kering}

Nilai rendemen pati kering yang dihasilkan PCRD dapat dilihat pada Tabel 3. Data yang disajikan tersebut menunjukkan bahwa nilai rendemen pati kering pada berbagai variasi suhu dan kadar air awal pati sagu perlakuan juga bervariasi yaitu antara 65-71\%. Data pada Tabel 3 menunjukkan bahwa rendemen pati kering yang dihasilkan kurang dari $80 \%$. Hal ini diduga terjadi karena beberapa pati kering halus ikut terbuang bersama uap air panas pada siklon output. Namun demikian, rendemen yang dihasilkan cukup baik, yaitu lebih dari 50\%. Nilai rendemen tersebut lebih tinggi dari pada nilai rendemen hasil pengering pati sagu menggunakan sinar matahari secara langsung (penjemuran) yaitu sekitar 50\% (Jading et al. 2013; Jading et al. 2014b).

\subsection{Nilai Kelayakan Investasi PCRD}

Biaya investasi dan operasi PCRD yaitu Rp. 186.879.200,-. Biaya pembuatan 1 unit PCRD adalah Rp. 179.200.000,. Nilai sisa yang diperoleh adalah Rp. 34.840.000,- dengan umur ekonomis 5 tahun, sehingga diperoleh nilai penyusutan sebesar Rp. 28.672.000,- dengan asumsi tingkat suku bunga $17 \%$..

Tabel 1. Kadar Akhir Pati Sagu

\begin{tabular}{cccc}
\hline \multirow{2}{*}{ Suhu pengeringan, $\mathbf{T}_{\mathbf{u}}\left({ }^{\circ} \mathbf{C}\right)$} & \multicolumn{3}{c}{ Kadar air akhir, $\mathbf{M}_{\mathbf{o b}} \mathbf{( \% )}$} \\
\cline { 2 - 4 } & $\mathbf{M}_{\mathbf{i b}} \mathbf{2 1 \%}$ & $\mathbf{M}_{\mathbf{i b}} \mathbf{3 1 \%}$ & $\mathbf{M}_{\mathbf{i b}} \mathbf{4 1 \%}$ \\
\hline 50 & 8,17 & 11,01 & 14,27 \\
75 & 7,20 & 10,50 & 13,23 \\
100 & 6,83 & 9,00 & 12,40 \\
\hline
\end{tabular}

Tabel 2. Efisiensi Pengeringan

\begin{tabular}{cccc}
\hline \multirow{2}{*}{ Suhu pengeringan, $\mathbf{T}_{\mathbf{u}}\left({ }^{\circ} \mathbf{C}\right)$} & \multicolumn{3}{c}{ Efisiensi pengeringan, $\eta_{\mathbf{p e}}, \mathbf{( \% )}$} \\
\cline { 2 - 4 } & $\mathbf{M}_{\mathbf{i b}} \mathbf{2 1 \%}$ & $\mathbf{M}_{\mathbf{i b}} \mathbf{3 1 \%}$ & $\mathbf{M}_{\mathbf{i b}} \mathbf{4 1 \%}$ \\
\hline 50 & 9,740 & 9,023 & 8,896 \\
75 & 9,689 & 9,050 & 8,766 \\
100 & 8,241 & 7,677 & 7,339 \\
\hline
\end{tabular}


Tabel 3. Rendemen Pati Kering

\begin{tabular}{cccc}
\hline \multirow{2}{*}{ Suhu pengeringan, $\mathbf{T}_{\mathbf{u}}\left({ }^{\circ} \mathbf{C}\right)$} & \multicolumn{3}{c}{ Rendemen pati sagu kering, $\eta_{\mathbf{b}}(\%)$} \\
\cline { 2 - 4 } & $\mathbf{M}_{\mathbf{i b}} \mathbf{2 1 \%}$ & $\mathbf{M}_{\mathbf{i b}} \mathbf{3 1 \%}$ & $\mathbf{M}_{\mathbf{i b}} \mathbf{4 1 \%}$ \\
\hline 50 & 71 & 70 & 66 \\
75 & 67 & 67 & 67 \\
100 & 73 & 67,7 & 65 \\
\hline
\end{tabular}

Asumsi harga beli pati sagu basah Rp. 1.000,-, dan harga jual pati kering Rp. 25.000,- maka diperoleh hasil penjualan atau penerimaan sebesar Rp. 384.000.000,-. Laba yang diperoleh setelah pada tahun ke-5 adalah Rp. 79.395.808,. Berdasarkan cashflow pada tahun ke-5, maka diperoleh saldo akhir sebesar Rp. 3.148.927.520,-

Nilai rata-rata EAT adalah sebesar Rp. 79.555.686,-, nilai rata-rata investasi $\mathrm{Rp}$. 93.439.600,- sehingga diperoleh nilai ARR sebesar $85,14 \%$, pay back periode 2,66 tahun, nilai IRR estimasi $17 \%$, nilai IRR actual $46 \%$, dan nilai NVP Rp. 66.239.356. Hal ini setara dengan tingkat suku bunga bank yang berlaku saat ini. Berdasarkan penilaian proyek dengan profitability index atau benefit cost ratio diperoleh nilai NPV sebesar Rp. 150.753.284,dengan nilai profitability index 1,81, sehingga investasi PCRD untuk pengeringan pati sagu layak dikembangkan. Jading et al. (2014a) juga telah menganalisis nilai ekonomi pengering pati sagu tipe crossflow vibro fluidized bed (CFVFB). Pengering tersebut layak diinvestasikan, namun Pay back periode pengering tersebut lebih lama yaitu 3,51 tahun apabila dibandingkan dengan PCRD 2,66 tahun. Selanjutnya Jading et al. (2014b) menganalisis nilai ekonomis pengering pati sagu Agro cross flow fluidized bed. Hasil analisis tersebut menunjukkan bahwa alat pengering pati sagu Agro crossflow fluidized bed layak dikembangkan dengan nilai pay back periodenya 2,48 , namun demikian kapasitasnya cukup kecil yaitu $35 \mathrm{~kg} /$ proses.

\section{KESIMPULAN DAN SARAN}

\subsection{Kesimpulan}

Telah diciptakan Pneumatic Conveying Ring Dryer (PCRD) skala kecil (mini) untuk pengeringan pati sagu dengan kapasitas $160 \mathrm{~kg}$ pati sagu kering per hari. Kadar air yang dihasilkan bervariasi sesuai dengan variasi suhu dan kadar air awal pati sagu dan telah memenuhi standar Nasional (SNI) No. 3729 tentang kadar air maksimum pati sagu (13\%), kecuali pada variasi suhu $50^{\circ} \mathrm{C}$ dan $75^{\circ} \mathrm{C}$ dengan kadar air awal $41 \%$ belum memenuhi SNI, yaitu lebih besar dari $13 \% \quad(14,27 \%$ dan $13,23 \%)$. Efisiensi pengeringan bervariasi antara antara 7,339\% sampai 9,689\%. Begitupula dengan rendemen pati sagu kering yang dihasilkan bervariasi antara $65 \%$ sampai $73 \%$. PCRD sangat layak dikembangkan menjadi pengering pati sagu skala komersial dengan nilai Pay back periode 2,66 tahun untuk mengembalikan modal awal sebesar Rp. 186.869.200.

\subsection{Saran}

Hasil penelitian ini perlu dilanjutkan dengan mengembangkan PCRD menjadi skala komersial (skala besar). Dengan pengembangan tersebut dapat meningkatkan produksi pati sagu kering.

\section{UCAPAN TERIMA KASIH}

Penulis mengucapkan terima kasih kepada Direktorat Riset dan Pengabdian Kepada Masyarakat (DRPM), Kementerian Riset, Teknologi, dan Pendidikan Tinggi (KEMRISTEKDIKTI) yang telah mendanai penelitian ini melalui skema Penelitian Terapan tahun 2020, dengan nomor kontrak: 089/SP2H/ LT/DRPM/IV/2020.

\section{DAFTAR PUSTAKA}

Ajao, K., dan Adegun, I. 2019. Performance Evaluation of a Locally Fabricated Mini Cassava Flash Dryer. Journal Agricultural Technology, 5(2): 281-289.

Badan Standar Nasional. 2008. Tepung sagu: SNI 3729. 
Brooker, D., Bakker-Arkema, F., dan Hall, C. 1992. Drying and Storage of Grains and Oilseeds. An avi Book Van Nostrand Reinhold.

Chapius, A., Precoppe, M., Meot, J., Sriroth, K., dan Tran, T. 2017. Pneumatic Drying of Cassava Starch: Numerical Analysis and Guidelines for the Design og Efficient Small-scale Dryers. Drying Technology An International Journal, 35(4): 393-408.

Husnan, S., dan Suwarsono. 1997. Studi Kelayakan Proyek (Kedua). UPP AMP YKPN.

Jading, A. 2018. Pengembangan Model Matematis dan Kecerdasan Buatan pada Perancangan Pneumatic Recirculation Conveying Dryer untuk Proses Pengeringan Pati Sagu. Universitas Gadjah Mada.

Jading, A., Bintoro, N., Sutiarso, L., dan Karyadi, J.N. 2018. Model Matematis Pengeringan Pati Sagu pada Pneumatic Conveying Recirculated Dryer. Agritech, 38(2): 217226.

Jading, A., Bintoro, N., Sutiarso, L., dan Wahyu, J. N. 2016. Analisis Efisiensi Pneumatic Conveying Recirculated Dryer untuk Pengeringan Bahan-bahan Tepung. Seminar Nasional Fakultas Pertanian UPN Veteran, 370-378.

Jading, A., Payung, P., Aman, W., dan Tethool, E. 2012. Modifikasi Tungku Gasifikasi untuk Pemanfaatan Limbah Biomassa Sebagai Sumber Energi Alternatif Pada Proses Pengeringan Hasil Pertanian. Istech, 4(2): 1-8.

Jading, A., Payung, P., Aman, W., dan Tethool, E. 2014a. Pengembangan dan Analisis Teknis-Finansial Alat Pengering Pati Sagu Model Agro Cross Flow Fluidized untuk Menunjang Agroindustri Sagu di Papua. Jurnal Teknologi Industri Pertanian, 24(2): 137-147.

Jading, A., Payung, P., dan Reniana. 2014b. Kajian Teknis-Ekonomis Alat Pengering Pati Sagu
Model Cross Flow Vibro Fluidized Bed. Agritech, 34(4): 448-455.

Jading, A., Tethool, E., dan Payung, P. 2019. Rancang Bangun Sistem Pengumpan Bahan pada Pneumatic Conveying Ring Dryer. Seminar Nasional Fakultas Teknik Universitas Wahid Hasyim.

Kusharjanto, B., Sundari, M., dan Himawanto, D. (2013). Rancang Bangun Prototipe Flash Dryer untuk Penegeringan Tepung Mocaf. Simposium Nasional RAPI XII, 74-78.

Kuye, A., Ayo, D., Sanni, L., Raji, A., Kwaya, E., Otuu, O., Asiru, W., Alenke, B., Abdulkareem, I., Bamkefa, B., Tarawali, G., Dixon, A. G., dan Okechukwu, R. 2011. Design and Fabrication of Flash Dryer for the Production of High Quality Cassava Flour. www.iita.org

Lydersen, A. 1978. Fluid Flow and Transfer. John Wiley dan Sons.

Nugroho, J., Primawati, dan Bintoro, N. 2012a. Pengeringan Umbi Kimpul (Xanthosoma sagittifolium Schott) Sawut dengan Pneumatic Dryer. Peran Keteknikan Pertanian Dalm Pembangunan Industri Pertanian Berkelanjutan Berbasis Kearifan Lokal.

Nugroho, J., Primawati, dan Bintoro, N. 2012b. Proses Pengeringan Singkong (Manihot esculenta crantz) Parut Dengan Menggunakan Pneumatic Dryer. Peran Keteknikan Pertanian Dalam Pembangunan Industri Pertanian Berkelanjutan Berbasis Kearifan Lokal, 105-112.

Paisal, E., Mahatta, F., dan Abimayu, B. 2018. Rancang Bangun Alat Pengering Tipe Tray Dryer. Agroteknika, 1(1): 31-38.

Prasnowo, M. dan Nurdin, S. 2019. Analisis Kelayakan Mesin Pengering Keripik Kentang. Agrointek, 13(1): 10-13.

Purbono, K., Ainuri, M., dan Suryandono. 2010. Rancang Bangun dan Uji Kelayakan 
Finansial Alat Pengering Mekanis untuk Pemenuhan Pasokan Eceng Gondok (Eichhornia crassipes) sebagai bahan baku kerajinan. Agritech, 30(2): 80-89.

Singh, R., dan Heldman, D. 2009. Introduction to Food Engineering (Fourth Edi). Academic Press ELSIVIER.

Suherman, Kuncoro, A. ., dan Kusworo, T. 2015. Eksperimental Study on Drying Kinetics of Cassava Starch in a Pneumatic Drying System. International Conference of
Chemical and Material Engineering (ICCME) AIP Conference, 1-6.

Tanaka, F., Uchino, T., Hamanaka, D., dan Atungulu, G. 2008. Mathematical Modelling of Pneumatic Drying of Rice Powder. Journal of Food Engineering, 88: 492-498.

Witdarko, Y., Bintoro, N., Suratmo, B., dan Rahardjo, B. 2016. Pemodelan Matematis Hubungan Kadar Air Tepung dengan Variabel Proses pada Pengering Mekanis Tepung Casava Menggunakan Pneumatic Dryer. Agritech, 36(1): 111-116. 